\title{
Iron Deficiency Anemia Associated with an Error of Iron Metabolism in Two Siblings *
}

\author{
Nasrollah T. Shahidi, David G. Nathan, and Louis K. Diamond \\ (From the Hematology Research Laboratory of the Children's Hospital Medical Center, the \\ Department of Medicine of the Peter Bent Brigham Hospital, and the De- \\ partments of Pediatrics and Medicine, Harvard Medical School, \\ Boston, Mass.)
}

This report describes the clinical and hematological characteristics of two young siblings with chronic hypochromic microcytic anemia and high serum iron concentrations. Further tests have revealed that neither patient suffers from thalassemia, hemoglobinopathy, or pyridoxine-responsive anemia. Subsequent examinations have disclosed an error in iron metabolism in these patients characterized by massive hepatic iron deposition and absent stainable bone marrow iron stores. The association of this discrepancy with the chronic hypochromic anemia present in these two siblings is unique and has stimulated a series of special studies concerning their iron metabolism.

\section{Case Reports}

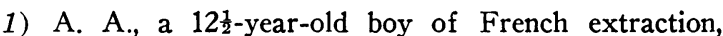
was born at term weighing 6 pounds 4 ounces. He was first seen in the Children's Hospital Medical Center at the age of $8 \frac{1}{2}$ years for treatment of refractory anemia; the patient had been pale most of his life. Various hematinics, such as iron, vitamin $B_{12}$, and folic acid, had been tried orally and parenterally, alone or in combination, without success.

Physical examination revealed an undersized, pale boy with dry, hyperkeratotic skin. The liver and spleen were palpable 3 and $4 \mathrm{~cm}$, respectively, below the costal margins.

The pertinent hematological findings are presented in Tables I and II. Stained films of the peripheral blood showed markedly hypochromic microcytic erythrocytes. There was little variation in size and shape of the red

* Submitted for publication May 14, 1963; accepted November 21, 1963.

Supported by grants from the John A. Hartford

Foundation and from the Medical Foundation, Inc.

Requests for reprints should be addressed to Louis $K$. Diamond, M.D., Children's Hospital Medical Center, Boston, Mass. cells, and no target cells were present. Nucleated red blood cells were not seen. The serum iron concentration (1) was elevated. The osmotic fragility test of incubated erythrocytes revealed that hemolysis began in $0.4 \%$ saline solution and was complete in $0.1 \%$ saline solution. An iliac bone marrow aspiration revealed a hypercellular specimen with erythroid hyperplasia (erythroid: myeloid ratio of $2.5: 1)$. Most of the erythroid elements were normoblasts with scanty and irregular basophilic cytoplasm. No megaloblastic changes were seen. Special iron stains (2) failed to show any siderocytes or sideroblasts; in addition, the reticulum cells were devoid of iron.

Liver function tests revealed a cephalin flocculation of $3+$, thymol flocculation of $4+$, and thymol turbidity of $3+$. Alkali resistant hemoglobin (3) and $A_{2}$ hemoglobin concentrations (4) were normal. Free erythrocyte protoporphyrin was increased (5).

Since this first admission, his status has remained unchanged. No blood transfusions have been required. He was given $250 \mathrm{cc}$ of sedimented erythrocytes before an open liver biopsy.

2) The sister, M. A., age 5, was first seen in the Children's Hospital Medical Center in May 1958, at the age of 10 months, because of anemia since early infancy. The anemia had also been unresponsive to oral and parenteral iron, vitamin $B_{12}$, and folic acid. The studies reported below were performed when she was 4 years and 8 months old.

Physical examination revealed a small, pale, irritable infant. Both height and weight were below the third percentile. The liver edge was palpated $6 \mathrm{~cm}$ below the right costal margin, and the spleen was felt $3 \mathrm{~cm}$ below the left costal margin.

The blood film, bone marrow smears, marrow iron stains, serum iron concentration, osmotic fragility test, $A_{2}$ hemoglobin level, and free erythrocyte protoporphyrin concentration were similar to those of her brother ( $\mathrm{Ta}$ ble II).

Since her second admission in March 1962, the patient has been followed in the Outpatient Department. There have been no important changes in her clinical and hematologic findings, nor has she required transfusion therapy. 
TABLE I

Hematological findings*

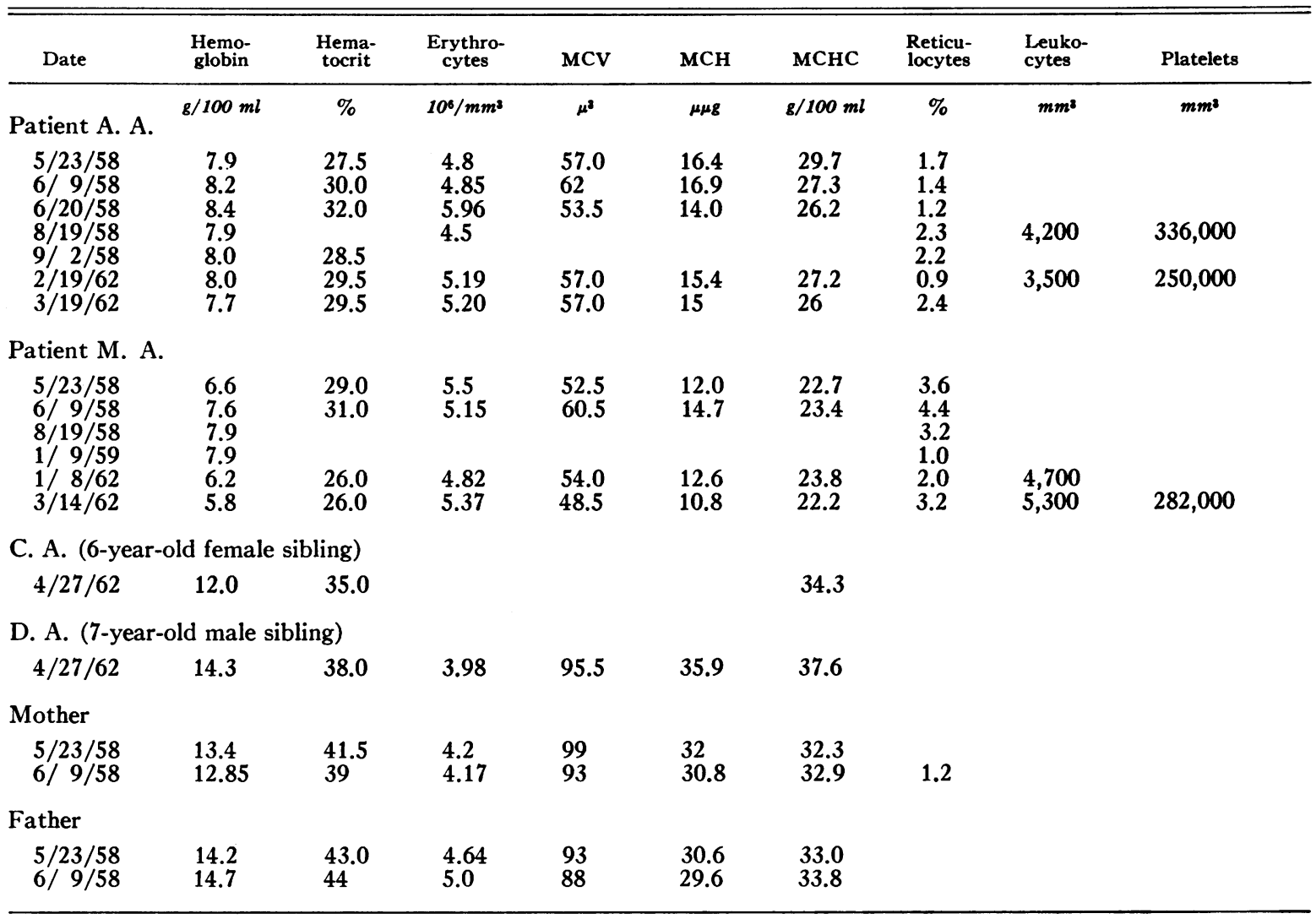

* $\mathrm{MCV}=$ mean corpuscular volume, $\mathrm{MCH}=$ mean corpuscular hemoglobin, and $\mathrm{MCHC}=$ mean corpuscular hemoglobin concentration.

TABLE II

Hematological findings*

\begin{tabular}{|c|c|c|c|c|c|c|c|c|}
\hline & Serum iron & $\begin{array}{c}\text { Total iron } \\
\text { binding } \\
\text { capacity }\end{array}$ & $\underset{\mathrm{A}_{2}}{\text { Hemoglobin }}$ & $\begin{array}{c}\text { Alkali } \\
\text { resistant } \\
\text { hemoglobin }\end{array}$ & FEP & ECP & $\underset{\text { ALA A }}{\text { Urinary }}$ & $\underset{\text { PBG }}{\text { Urinary }}$ \\
\hline & $\mu \mathrm{g} / 100 \mathrm{ml}$ & $\mu \mathrm{g} / 100 \mathrm{ml}$ & $\%$ & $\%$ & $\begin{array}{c}\mu g / 100 m l \\
R B C\end{array}$ & $\underset{R B C}{\mu g / 100 m l}$ & $\underset{\text { hours }}{m g / 24}$ & $\begin{array}{c}m g / 24 \\
\text { hours }\end{array}$ \\
\hline A. A. & $\begin{array}{l}170- \\
250\end{array}$ & $\begin{array}{l}300- \\
450\end{array}$ & 1.9 & 2.3 & 116 & 0.6 & .42 & .5 \\
\hline M. A. & $\begin{array}{l}173- \\
200\end{array}$ & $\begin{array}{l}350- \\
440\end{array}$ & 2.3 & $4.7 \dagger$ & 146 & 0.4 & .20 & 0 \\
\hline Father & 100 & 496 & & 1.5 & 67.8 & & & \\
\hline Mother & 94 & 394 & & 1.3 & 42.5 & & & \\
\hline D. A. & 88 & 416 & & & 37.4 & & & \\
\hline C. A. & 60 & 336 & & & 43 & & & \\
\hline $\begin{array}{l}\text { Normal } \\
\text { range }\end{array}$ & $\begin{array}{l}55- \\
150\end{array}$ & $\begin{array}{l}250- \\
420\end{array}$ & $1.7-3.1$ & $<2$ & $22-59$ & $<3$ & $<.5$ & $<2$ \\
\hline
\end{tabular}

${ }^{*} \mathrm{FEP}=$ free erythrocyte protoporphyrin (5), ECP = erythrocyte coproporphyrin (6), ALA = delta-aminolevulinic acid (7), and PBG = porphobilinogen (7).

$\dagger$ Determined at 10 months of age. 


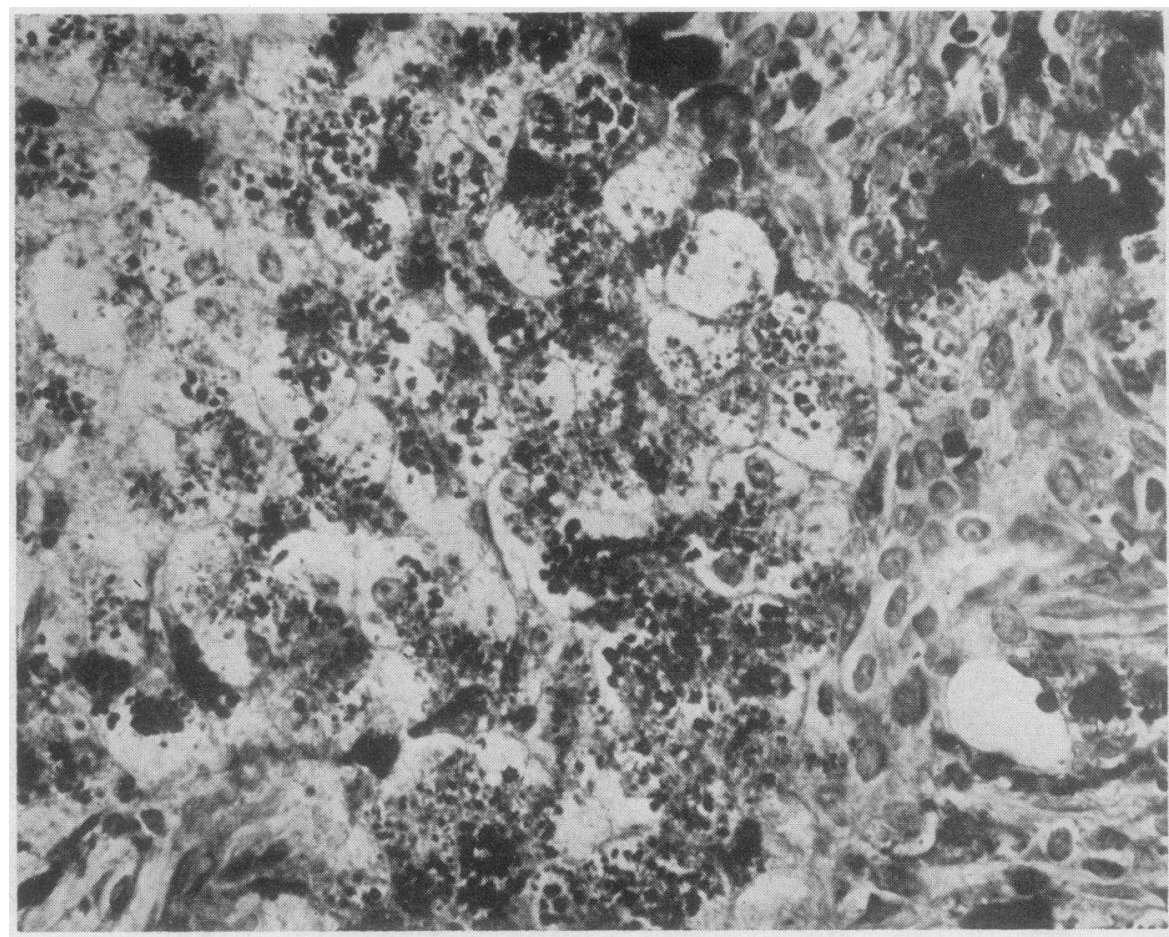

Fig. 1. Prussian blue-stained section from liver biopsy of patient A. A. Practically all the ferruginous granules were present in the liver cells. The liver biopsy of patient M. A. showed a similar pattern.

\section{Methods and Results}

Because of the similarity of the syndrome in these two siblings, both patients were thought to suffer from the same disease. Consequently, some of the studies of the boy were not repeated in the younger sibling.

\section{Biopsies}

Liver biopsy was obtained from both patients. Microscopic examination of the sections from patient A. A. revealed mild fibrosis in portal areas extending diffusely into the lobules in some regions. These fibrotic changes were not present in patient M. A. A fine, greenish-yellow pigment, strongly Prussian-blue-positive, was present in many of the liver cells in both patients (Figure 1). The great majority of Kupffer cells, which were inconspicuous in both patients, contained no pigment. The pigment was most abundant in the cells surrounding the portal spaces and in the interlobular connective tissue, but it was absent in the liver cells around the central veins. No iron pigment was found in the ducts or smooth muscle. Immunofluorescent studies with fluorescent human anti-apoferritin rabbit serum indicated that, in addition to hemosiderin, the liver cells also contained large amounts of ferritin. ${ }^{1}$

Sternal biopsy was performed in both patients. In both cases the bone marrow revealed normal myelopoiesis with increased erythroid activity. Megakaryocytes were present in adequate numbers; macrophages were inconspicuous. Prussian blue staining failed to reveal any iron granules in the bone marrow of either patient.

Gastric and duodenal biopsies were obtained from both patients. The gastric and duodenal mucosa showed no abnormality. No iron pigment could be detected. Prussian blue stains of a section of a skin biopsy and of smears of urine sediment and sputum were also examined. These failed to show stainable iron. In addition, the

1 We are indebted to Dr. John M. Craig for the immunofluorescent studies of the liver sections and to $\mathrm{Dr}$. Gordon Vawter for the preparation and study of the biopsies reported here. 


\section{A.A. HOMOLOGOUS PLASMA}
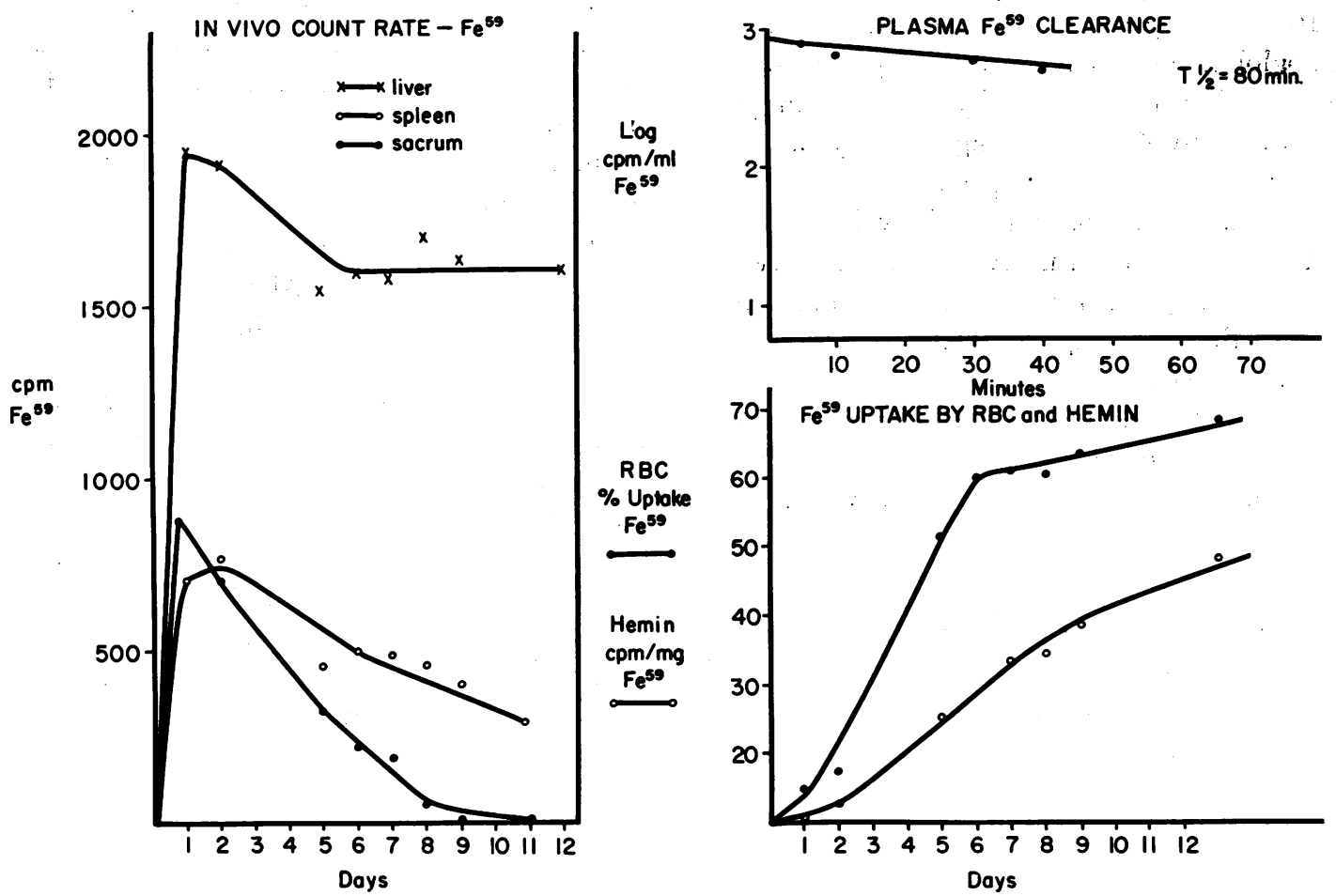

Fig. 2. Ferrokinetics in patient A. A. After the administration of Fe ${ }^{59}$ bound to HOMOLOGOUS PLASMA.

liver and marrow biopsies were stained for iron and reviewed as unknowns. ${ }^{2}$

\section{Ferrokinetics and erythrocyte survival}

Methods. Studies of plasma and red cell iron turnover, together with in vivo measurement of iron localization, were performed with $\mathrm{Fe}^{59}$ citrate by previously described methods (8-10). In addition, hemin was isolated from peripheral blood (11), and its $\mathrm{Fe}^{59}$ specific activity was assessed. Patient A. A. first received $4 \mu \mathrm{c} \mathrm{Fe}^{59}$ citrate incubated with $10 \mathrm{ml}$ of compatible homologous plasma. The amount of carrier iron was calculated to be within the iron binding capacity of the plasma for this and subsequent studies. During the second study of A. A., he received 5 $\mu \mathrm{c} \mathrm{Fe}^{59}$ citrate bound to autologous plasma. Twenty $\mu \mathrm{c}$ of $\mathrm{Na}_{2} \mathrm{Cr}^{51} \mathrm{O}_{4}$ was bound to autolo-

2 By Dr. Richard MacDonald, Mallory Institute of Pathology, Boston City Hospital, whose assistance and interest we appreciated. The results he found were the same as those of Drs. Vawter and Craig. gous red cells for measurement of red cell survival during the first $\mathrm{Fe}^{59}$ study (10).

Patient M. A. received a single dose of $2 \mu \mathrm{c}$ $\mathrm{Fe}^{59}$ citrate bound to autologous plasma. Plasma iron clearance, red cell iron turnover, rate of appearance of $\mathrm{Fe}^{59}$ in circulating hemin, and in vivo localization of $\mathrm{Fe}^{59}$ were estimated by the techniques described above.

Results. In patient A. A., the results of studies performed in vivo both with homologous and with autologous $\mathrm{Fe}^{59}$-labeled plasma were not substantially different (Figures 2 and 3 ). The salient findings were these: normal plasma $\mathrm{Fe}^{59}$ clearance despite elevation of the serum iron, rapid accumulation of a substantial fraction of the $\mathrm{Fe}^{59}$ in the liver, 45 to $65 \%$ of the $\mathrm{Fe}^{59}$ in the red cells 10 days after its administration, and appearance of $\mathrm{Fe}^{59}$ in circulating red cells and in hemin at identical and normal rates. The latter is more clearly demonstrated in Figure 6. The red cell life span as estimated with $\mathrm{Cr}^{51}$ was normal. The total red cell volume was $510 \mathrm{ml}$ or 16.1 
$\mathrm{ml}$ per $\mathrm{kg}$ body weight. At a red cell renewal rate of $1 \%$ per day, the daily red cell production was $0.16 \mathrm{ml}$ per $\mathrm{kg}$ per day. The mean corpuscular hemoglobin concentration was $27 \mathrm{~g}$ per $100 \mathrm{ml}$ red cells. Therefore, the daily hemoglobin production was only $43 \mathrm{mg}$ per $\mathrm{kg}$ per day, a value approximately half of that predicted for a normal individual. Calculation of daily hemoglobin production from $\mathrm{Fe}^{59}$ turnover data produced a value of $135 \mathrm{mg}$ per $\mathrm{kg}$ per day, approximately three times the actual figure. This error was undoubtedly induced by marked overestimation of the rate of $\mathrm{Fe}^{59}$ accumulation in the marrow (12). The contribution of the plasma: liver equilibrium to the turnover of $\mathrm{Fe}^{59}$ in the plasma was underestimated.

The findings concerning patient M. A. were very similar to those of her brother (Figures 4 and 6 ). There was a higher accumulation of $\mathrm{Fe}^{59}$ in the red cells, hence a less striking accumulation in the liver. The $\mathrm{Cr}^{51}$ red cell life span was not estimated.

\section{Transferrin and cellular "receptor sites"}

To investigate the possibility of a qualitative defect of transferrin or of the ability of marrow cells to remove iron from transferrin, the following studies were performed.

One $\mu \mathrm{c}$ of $\mathrm{Fe}^{59}$ was incubated with $2 \mathrm{ml}$ of serum from patient A. A. for 30 minutes at room temperature. A sample of the $\mathrm{Fe}^{59}$ serum complex was subjected to starch gel electrophoresis (13). The transferrin band was single and corresponded to the transferrin $C$ phenotype. The starch gel plate was subsequently covered with a $3-\times 4$-inch $\mathrm{X}$-ray film and was stored in the dark for 3 days. The resulting radioautograph corresponded closely to the position of the transferrin band.

Five $\mu \mathrm{c}$ of $\mathrm{Fe}^{59}$ citrate was incubated with 10 $\mathrm{ml}$ of plasma from patient A. A. The labeled plasma was then administered to a normal volunteer. The plasma iron turnover, in vivo localization of $\mathrm{Fe}^{59}$, and rate of appearance of $\mathrm{Fe}^{59}$ in the newly formed erythrocytes were entirely normal (Figures 5 and 6).

\section{A.A. AUTOLOGOUS PLASMA}
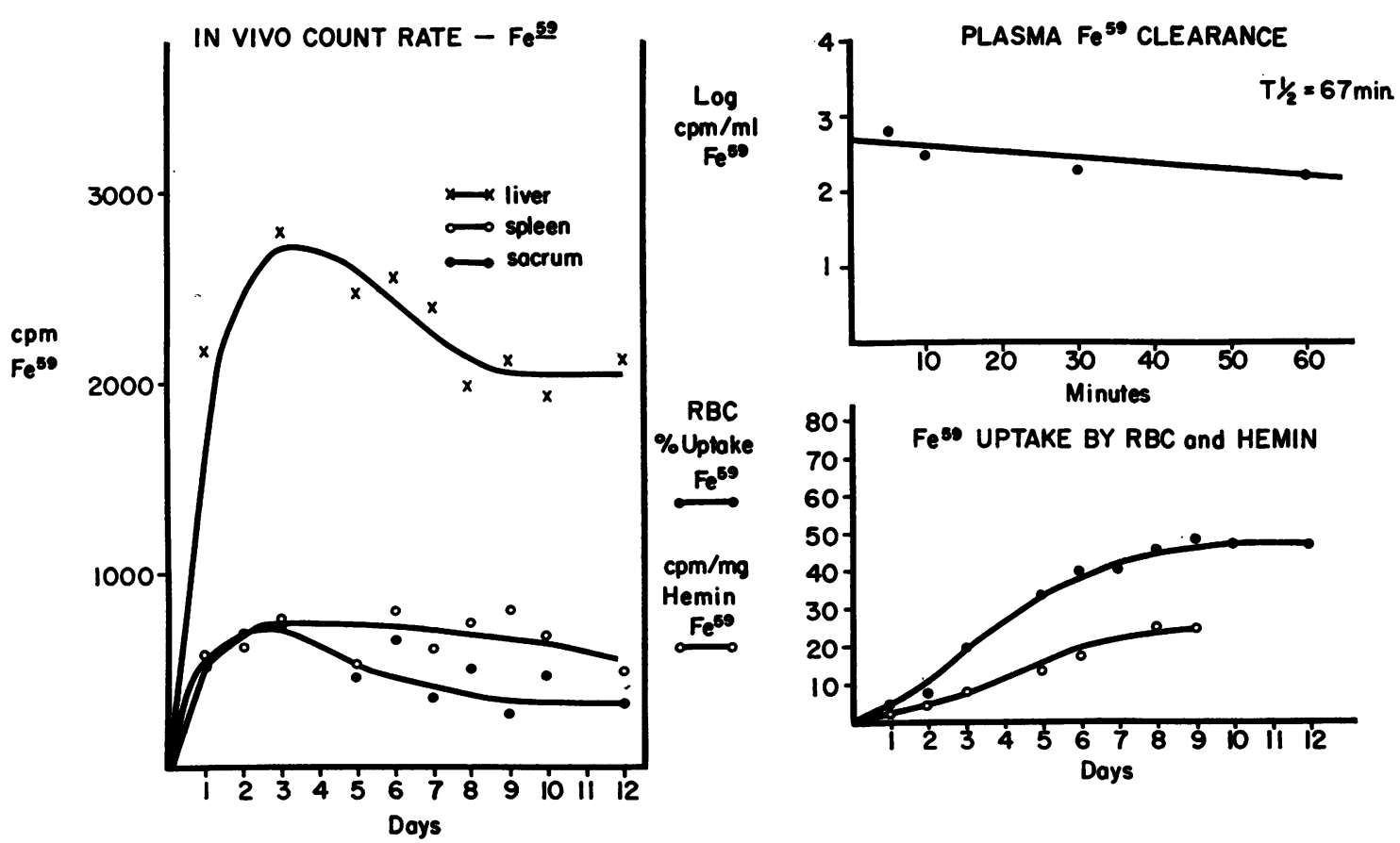

Fig. 3. Ferrokinetics in patient A. A. After the administration of Fe bound to AUTOLOgOUS PLASMA. 


\section{M.A. AUTOLOGOUS PLASMA}
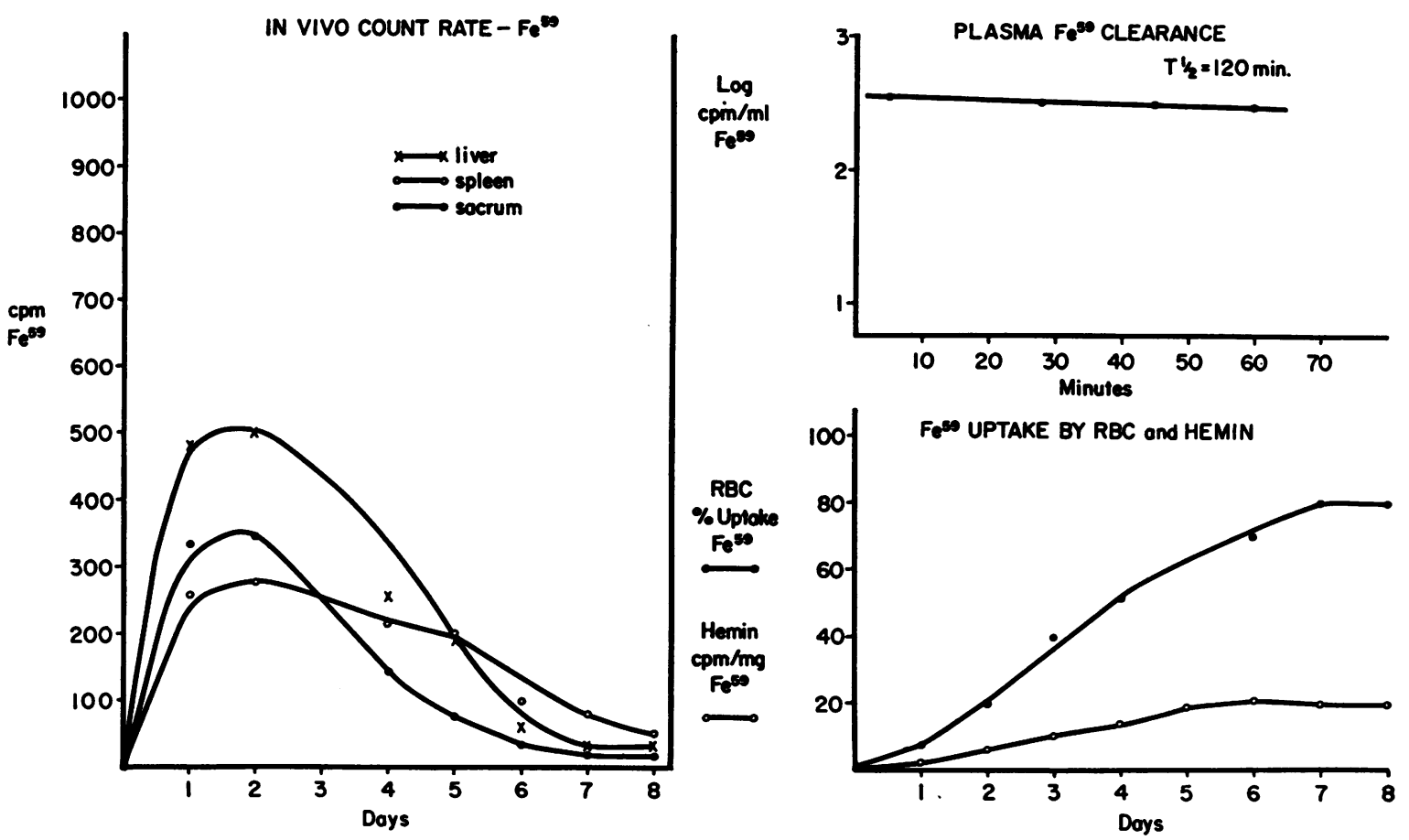

Fig. 4. Ferrokinetics in patient M. A. After the administration of Fe ${ }^{\text {so }}$ bound to AUTOLOGOUS PLASMA.

To examine the intrinsic ability of A. A.'s reticulocytes to transfer iron into hemoglobin from homologous transferrin (14), the following experiment was performed. A $15 \%$ suspension of A. A.'s reticulocytes was derived from repeated centrifugation and harvesting of upper layer cells. One $\mathrm{ml}$ of these cells was incubated in $4 \mathrm{ml} \mathrm{ho-}$ mologous plasma for 1 hour at $37^{\circ} \mathrm{C}$ under $20 \%$ oxygen, $5 \%$ carbon dioxide, and $75 \%$ nitrogen. The plasma iron concentration was $100 \mu \mathrm{g}$ per $100 \mathrm{ml}$, and $2 \mu \mathrm{c} \mathrm{Fe} \mathrm{F}^{59}$ citrate ( $0.2 \mu \mathrm{g}$ of iron) was added to the plasma 3 hours before incubation. The percentage of uptake of the $\mathrm{Fe}^{59}$ by the reticulocytes was calculated after incubation and five saline washes. The fraction of the total uptake incorporated into hemoglobin was assessed by comparison of the hemoglobin specific activity of whole hemolysate with the hemoglobin specific activity of a stroma-free preparation. The results were compared with a similar study of a suspension of $33 \%$ reticulocytes derived from another patient during his response to vitamin $B_{12}$ therapy of pernicious anemia. A sample of the same plasma was used during the incubation. The results of both studies were quite similar. A. A.'s reticulocytes incorporated $12 \%$ of the isotope, and the pernicious anemia patient's reticulocytes incorporated $7.8 \%$. The fraction of the total uptake incorporated into hemoglobin was $58 \%$ for A. A.'s reticulocytes and $45 \%$ for pernicious anemia reticulocytes. There was therefore gross equality in the two studies.

A study of A. A.'s bone marrow cells incubated with $\mathrm{Fe}^{59}$-labeled autologous and homologous plasma provided the same conclusions. No impairment of transfer of $\mathrm{Fe}^{59}$ from autologous or homologous transferrin to hemoglobin could be detected.

Effect of iron administration and reticuloendothelial clearance of colloidal particles

The absence of demonstrable iron in the bone marrow and in the vast majority of Kupffer cells in the liver suggested that macrophages in these patients might be deficient in their ability to pha- 
gocytize iron and particulate matter. Consequently, the following experiments were performed in patient A. A.

Infusion of colloidal iron. Two hundred fifty $\mathrm{mg}$ of iron saccharide was added to $250 \mathrm{cc}$ of $5 \%$ dextrose, and the solution was infused into patient A. A. over a 4-hour period without any incident. This procedure was repeated the next day. A bone marrow aspiration was performed after the second infusion. No siderocytes or sideroblasts could be demonstrated. A few hemosiderin granules within macrophages were seen, but very rarely. Normally macrophages containing iron granules can be readily demonstrated in large numbers in the bone marrow aspirate after colloidal iron infusion (15). The iron saccharide infusion did not result in any significant rise in the hemoglobin concentration or reticulocyte count.

Infusion of colloidal gold. The injection of colloidal gold $\left(\mathrm{Au}^{198}\right)$ into the circulation of humans or animals is followed by a rapid fall in radioactivity that attains half of its initial value within the first 5 minutes (16). Should reticu- lum cells be unable to remove the colloidal gold because of an inherited or artificially created block, the rate of disappearance of radioactivity might decrease considerably. To evaluate the capacity of the reticuloendothelial system to remove particles from the circulation, patient A. A. was given $1 \mu \mathrm{c}$ of colloidal $\mathrm{Au}^{198}$ intravenously. A polyethylene catheter was inserted in the antecubital vein of the other arm, and blood specimens were drawn from the catheter $2,4,8,15$, and 32 minutes after the injection for estimation of the radioactivity of whole blood. The injected $A u^{198}$ disappeared very rapidly. The radioactivity decreased to one-half the activity of the first specimen in $2 \frac{1}{2}$ minutes, and hepatic radioactivity rapidly increased.

\section{Family studies}

Because of the findings in the children, other members of the family were investigated. As seen in Tables I and II, these studies did not reveal any abnormalities. Ferrokinetic studies with $\mathrm{Fe}^{59}$, also performed in both parents, revealed no abnormality.

\section{J.G. NORMAL WTH A.A. PLASMA}
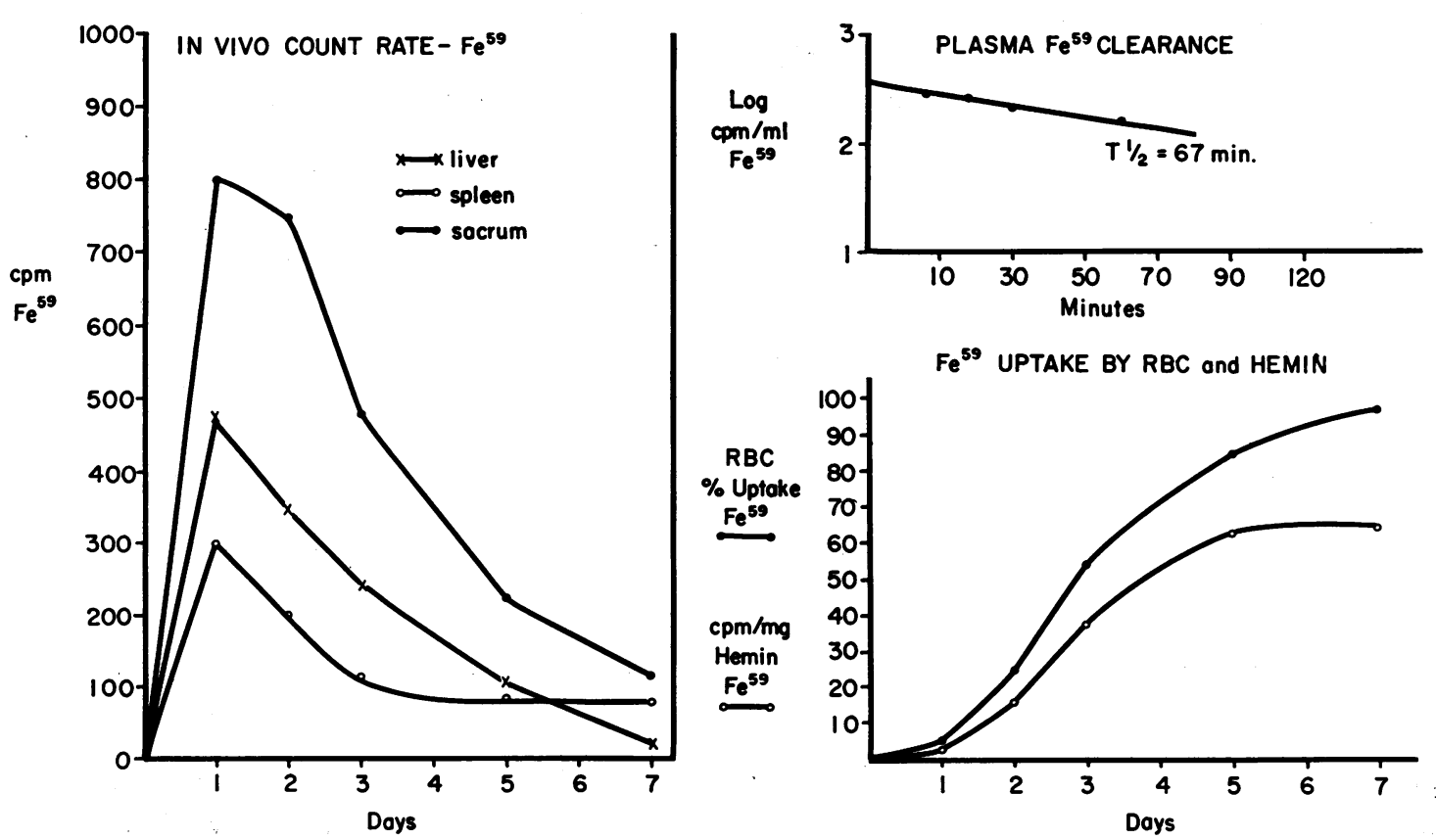

Fig. 5. Ferrokinetics in a NORMal volunteer haVing ReCEIVEd FE ${ }^{59}$ bound to PLASMa from PATIENT A. A. 
INCORPORATION OF Fes? BY RBC $\longrightarrow$ AND HEMIN $\leadsto$

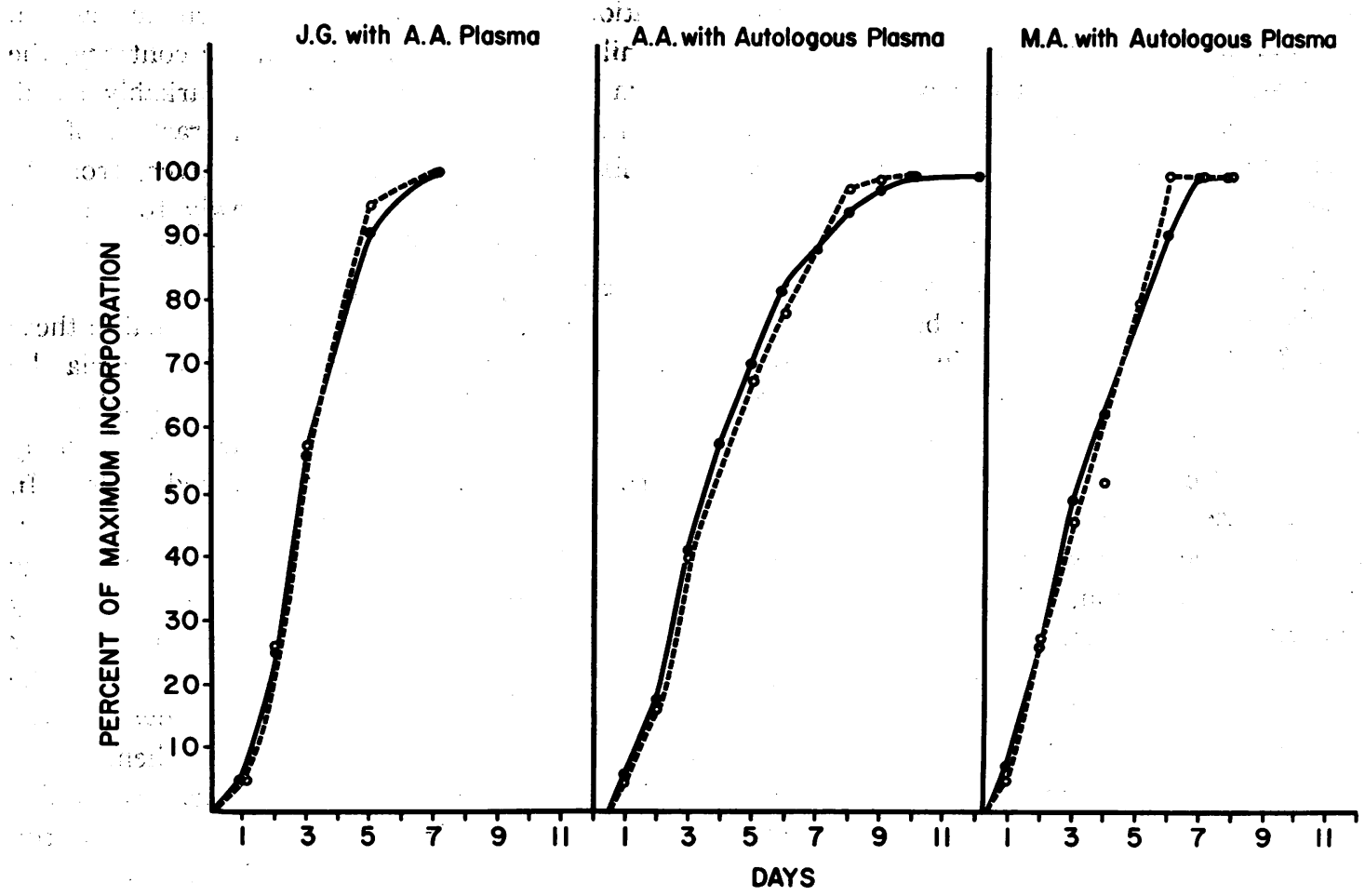

Fig. 6. The rate of appearance of Fe ${ }^{\text {so }}$ in the red cells and in isolated hemin in J. G., A

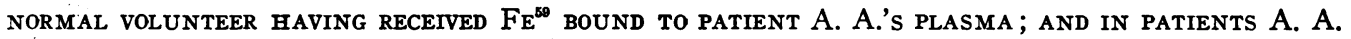
AND M. A., Who Were GIVEN FE $\mathbf{E}^{50}$ bOUNd to AUtologous plasma. The ordinate is plotted as the percentage of the maximal incorporation of radioactivity by either red blood cells or hemin.

\section{Therapeutic trials}

The therapeutic trials were performed only in the boy who, in addition to the usual hematinics, received sufficient pyridoxine $(17-20)$ and oral liver extract (21) to exclude any potential benefit from these substances. Moreover, a tryptophan loading test performed before the administration of pyridoxine failed to reveal any abnormal tryptophan metabolites, such as 3-hydroxykynurenine or anthranilic acid.

To examine the possibility that a large dose of transferrin would augment the incorporation of iron into erythroid cells by increasing the transferrin-erythroid cell iron exchange (14), he was infused with $10 \mathrm{~g}$ of purified iron-saturated transferrin. The serum iron and unsaturated iron binding capacity (UIBC) were measured before and after infusion and were followed over several days. Before the infusion, the serum iron and UIBC were, respectively, $170 \mu \mathrm{g}$ and $130 \mu \mathrm{g}$ per $100 \mathrm{ml}$. Twelve hours after the infusion, they reached values as high as $592 \mu \mathrm{g}$ for serum iron, and as low as $76 \mu \mathrm{g}$ for UIBC. Over the following 6 days, the concentration of iron in the serum decreased slowly to $312 \mu \mathrm{g}$, whereas the UIBC rose to $300 \mu \mathrm{g}$ per $100 \mathrm{ml}^{3}$ The patient's hemoglobin concentration and reticulocyte count were measured daily for 10 days after the infusion of transferrin. No significant changes were observed.

\section{Discussion}

Most of the hematological findings in these patients were characteristic of iron-deficiency anemia. Erythrocytosis with hypochromia and microcytosis, increased free erythrocyte protoporphyrin, absent stainable bone marrow iron

3 The detachment of iron from transferrin in vivo has been more precisely demonstrated with $\mathrm{I}^{181}-\mathrm{Fe}^{50}$ labeled transferrin (22). 
stores, and absent sideroblasts were compatible with this diagnosis. Indeed, the anemia observed in these children is due to iron deficiency of the bone marrow, but the associated elevation of serum iron concentration and massive hepatic iron deposition are unique features that considerably complicate the problem.

These two children differ markedly from patients with refractory hypochromic hypersideremic anemia whose case histories have been reported to date (23-38). Three major functions (iron stores, erythrocyte life span, and kinetics of $\mathrm{Fe}^{59}$ utilization) distinguish hypersideremic anemia from the present cases.

1) In the cases of hypersideremic anemia described to date, the marrow and hepatic reticulum cells are loaded with iron, sideroblasts are abundant, and hepatic cells often have increased iron granules. By contrast, iron is conspicuously absent from the marrow of the children reported here, and iron infusion did not significantly increase the bone marrow iron stores of patient A. A. The hepatic cells, however, are laden with iron. This disparity between the hepatic and marrow iron storage sites is unique in our experience and contrasts with the studies of Gale, Torrance, and Bothwell (39), which emphasize the linear relationship between hepatic and marrow stainable iron stores in normal individuals and in individuals with iron loading syndromes.

2) The red cell life span of patients with hypochromic hypersideremic anemia is usually moderately shortened, but in patient A. A. the life span was normal, as estimated with $\mathrm{Cr}^{51}$.

3) In hypochromic hypersideremic anemia, plasma $\mathrm{Fe}^{59}$ clearance is often rapid, with accumulation of $\mathrm{Fe}^{59}$ in the marrow and liver, but the subsequent appearance of $\mathrm{Fe}^{59}$ in peripheral red cells is slow and markedly decreased. Thus, in previously studied cases $(25,27-30,34)$, the calculated percentage of uptake of $\mathrm{Fe}^{59}$ by red cells, 10 days after iv administration of radioiron, varied from 5 to $36 \%$. Of this reduced $\mathrm{Fe}^{59}$ incorporation, an even smaller fraction may actually be located in the hemoglobin. Much of the labeled iron may be detected in the stroma (35). These findings are consistent with the high ratio of nonhemoglobin iron to hemoglobin iron in the red cells of patients with hypochromic hypersideremic anemia $(29,30)$. Various defects in heme syn- thesis have been evoked to account for these observations, none of which have been detected in the children reported here. On the contrary, the plasma iron clearance was not remarkably rapid, and although an abnormally high fraction of the administered $\mathrm{Fe}^{59}$ appeared in the liver, from 45 to $80 \%$ was incorporated into newly formed red cells. In addition, $\mathrm{F}^{59}$ appeared in the red cells and the hemoglobin at equal rates.

To be sure, the $\mathrm{Fe}^{59}$ data are not normal in these children. In ordinary iron deficiency anemia the rate of removal of $\mathrm{Fe}^{59}$ from hyposideremic plasma is very rapid, and all of the $\mathrm{Fe}^{59}$ is swiftly incorporated into newly formed red cells. In these children, only the bone marrow is iron deficient. The administered $\mathrm{Fe}^{59}$ mixes in a large plasma iron pool; a significant moiety is rapidly deposited in the liver; the remainder is utilized for hemoglobin synthesis by the marrow. But the amount of iron utilized by the marrow is obviously inadequate for the demands of hemoglobin synthesis in these children. The marrow, which requires a larger fraction of the total body iron pool, fails to partake sufficiently of the extramedullary sideroplethora, and iron deficiency anemia ensues. The nature of this famine in the face of plenty is subject to conjecture, since none of the studies reported here have revealed its mechanism. That the abnormality is probably congential is suggested by the appearance of the disorder in two young siblings. In addition, the nature of the congenital lesion appears to be one of insufficient iron delivery to the erythroid marrow rather than underutilization of iron and ineffective erythropoiesis. Two linked observations emphasize the lesion of iron delivery. These are the absence of stainable iron in the marrow in a hypochromic anemia and the failure to achieve $100 \%$ uptake of a tracer dose of iron by the red cells despite deficient marrow iron stores.

Several possibilties regarding the nature of the insufficient iron delivery to the marrow in these children have been considered, but none is definitive.

1) An abnormality of transferrin might result in a significant decline in the rate of delivery of iron to the developing erythroid cells of the marrow. This possibility is considered unlikely because of the normal quantity and electrophoretic mobility of A. A.'s transferrin, lack of significant 
differences in the studies of $\mathrm{Fe}^{59}$ kinetics with either homologous or autologous plasma, and, most important, the normal findings after injection of A. A.'s $\mathrm{Fe}^{59}$-labeled plasma into a normal individual.

2) A defect involving the receptor sites of the immature erythroid cells for transferrin (14) might occur, but the in vitro studies of bone marrow cells and reticulocytes of A. A. did not reveal an obvious failure of the erythroid cells to incorporate iron from transferrin.

3) The liver may act as a primary "depot" for transferrin-bound iron. The biopsy studies revealed absence of iron in any tissues examined except the liver. A fixed percentage of the plasma iron could conceivably be deposited in the hepatic cells before it can reach the marrow and hepatic release of iron be impaired. In such a circumstance, the liver iron stores would steadily increase, and there might be an initial decline in the plasma iron values. Depending upon the rate constants involved in the plasma: liver equilibrium and the total liver iron pool, the plasma iron level might then become normal or even elevated. At the point at which the plasma iron level became normal or elevated, however, the bone marrow erythroid cells should receive an adequate flow of iron. The latter is not the case in these children.

4) The absence of stainable iron in reticulum cells of the marrow and its virtual absence in Kupffer cells suggests that the basic lesion might be a failure of the macrophages to accumulate iron from either transferrin or phagocytized erythroid cells. If, as Bessis and Breton-Gorius (40, 41) have proposed, the marrow reticulum cells contribute a significant fraction of the iron necessary for hemoglobinization of erythroid cells, failure of reticulum cells to store iron could result in the syndrome observed in these children; the relatively insufficient iron uptake by these hypochromic erythrocytes may be the result of this defect. The iron that failed to appear in the patients' red cells and lodged in the liver may represent that amount of iron which under normal conditions takes the macrophage route. The fact that a patient with a congenital absence of transferrin (32) did produce hemoglobin, albeit in reduced amounts, supports the possibility of an ad- ditional source of iron for erythroid cells-perhaps the reticulum cells of the bone marrow.

There is much controversy (42) regarding the possible role of the reticulum cell as an intermediary between transferrin iron and hemoglobin iron. Studies of canine iron metabolism with $\mathrm{Fe}^{59}$ do not suggest an important contribution to hemoglobin synthesis by the marrow reticulum cell (43). Indeed, one clinical experience belies such a function. A patient with hereditary hemorrhagic telangiectasia has been observed at the Peter Bent Brigham Hospital for many years. $\mathrm{He}$ has received massive amounts of parenteral saccharated iron oxide and iron dextran. His red cells are severely hypochromic; his serum iron value 1 week after a $500-\mathrm{mg}$ intravenous dose of iron dextran is usually 10 to $20 \mu \mathrm{g}$ per $100 \mathrm{ml}$. Yet the reticulum cells of the bone marrow are so full of iron that the marrow smear appears grossly blue after Prussian blue staining. Certainly these cells are unable to provide sufficient iron for hemoglobinization. Only when the plasma iron is normalized does this patient increase his hemoglobin production.

Thus, various inquiries into the nature of the defect in iron metabolism that exists in the children reported here have not led to definition either of their pathophysiology or their treatment. They have, however, provided evidence that normal saturated transferrin alone is not sufficient to furnish the marrow with a flow of iron adequate for the demands of hemoglobin synthesis.

\section{Summary}

A new type of hypochromic microcytic anemia associated with an error of iron metabolism has been described in two siblings. Both children have had anemia since infancy, and all therapeutic efforts have been unsuccessful. Special investigations, including studies of transferrin and ferrokinetics, showed no defect in transferrin or the qualitative aspects of heme synthesis. Iron stains revealed a marked discrepancy between the iron storage sites. Although the liver parenchymal cells were surcharged with ferruginous material, the Kupffer cells and the macrophages and erythroid cells in the bone marrow contained none. The existence of iron-deficient erythrocytes in these patients despite adequate transferrin-iron complex 
suggests that this complex does not alone assure iron delivery to the erythroid bone marrow sufficient for the demands of hemoglobin synthesis.

\section{Acknowledgments}

The authors are grateful to Dr. Jay Katz and Dr. Thomas Gabuzda for many helpful suggestions and manuscript reviews.

\section{References}

1. Schade, A. L., J. Oyama, R. W. Reinhart, and J. R. Miller. Bound iron and unsaturated iron-binding capacity of serum; rapid and reliable quantitative determination. Proc. Soc. exp. Biol. (N. Y.) 1954, 87, 443.

2. Kaplan, E., W. W. Zuelzer, and C. Mouriquand. Sideroblasts: a study of stainable nonhemoglobin iron in marrow normoblasts. Blood 1954, 9, 203.

3. Singer, K., A. I. Chernoff, and L. Singer. Studies on abnormal hemoglobins. I. Their demonstration in sickle cell anemia and other hematologic disorders by means of alkali denaturation. Blood 1951, 6, 413.

4. Kunkel, H. G., and G. Wallenius. New hemoglobin in normal adult blood. Science 1955, 122, 288.

5. Grinstein, M., and M. M. Wintrobe. Spectrophotometric micromethod for the quantitative determination of the free erythrocyte protoporphyrin. J. biol. Chem. 1948, 172, 459.

6. Schwartz, S., and H. M. Wikoff. The relation of erythrocyte coproporphyrin and protoporphyrin to erythropoiesis. J. biol. Chem. 1952, 194, 563.

7. Mauzerall, D., and S. Granick. The occurrence and determination of delta-aminolevulinic acid and porphobilinogen in urine. J. biol. Chem. 1956, 219, 435.

8. Huff, R. L., T. G. Hennessy, R. E. Austin, J. F. Garcia, B. M. Roberts, and J. H. Lawrence. Plasma and red cell iron turnover in normal subjects and in patients having various hematopoietic disorders. J. clin. Invest. 1950, 29, 1041.

9. Elmlinger, P. J., R. L. Huff, C. A. Tobias, and J. H. Lawrence. Iron turnover abnormalities in patients having anemia: serial blood and in vivo tissue studies with $\mathrm{Fe}^{58}$. Acta haemat. (Basel) 1953, 9, 73.

10. Read, R. C., G. W. Wilson, and F. H. Gardner. The use of radioactive sodium chromate to evaluate the life span of the red blood cell in health and certain hematologic disorders. Amer. J. Med. Sci. 1954, 228, 40.

11. Labbe, R. F., and G. Nishida. A new method of hemin isolation. Biochim. biophys. Acta (Amst.) 1957, 26, 437.

12. Pollycove, M., and R. Mortimer. The quantitative determination of iron kinetics and hemoglobin synthesis in human subjects. J. clin. Invest. 1961, 40, 753 .
13. Smithies, O. An improved procedure for starch-gel electrophoresis: further variations in the serum proteins of normal individuals. Biochem. J. 1959, $71,585$.

14. Jandl, J. H., J. K. Inman, R. L. Simmons, and D. W. Allan. Transfer of iron from serum iron-binding protein to human reticulocytes. J. clin. Invest. 1959, 38, 161.

15. Coleman, D. H., A. R. Stevens, Jr., and C. A. Finch. The treatment of iron deficiency anemia. Blood $1955,10,567$.

16. Krook, H. Circulatory studies in liver cirrhosis. Acta med. scand. (suppl.) 1956, 318, 121.

17. Harris, J. W., R. M. Whittington, R. Weisman, Jr., and D. L. Horrigan. Pyridoxine responsive anemia in the human adult. Proc. Soc. exp. Biol. (N. Y.) 1956, 91, 427.

18. Bishop, R. C., and F. H. Bethell. Hereditary hypochromic anemia with transfusion hemosiderosis treated with pyridoxine. N. Engl. J. Med. 1959, 261, 486.

19. Erslev, A. J., A. A. Lear, and W. B. Castle. Pyridoxine-responsive anemia. New Engl. J. Med. 1960, 262, 1209.

20. Verloop, M. C., and W. Rademaker. Anaemia due to pyridoxine deficiency in man. Brit. J. Haemat. 1960, 6, 66 .

21. Horrigan, D. L., R. M. Whittington, R. F. Weisman, and J. W. Harris. Hypochromic anemia with hyperferricemia responding to oral crude liver extract. Amer. J. Med. 1957, 22, 99.

22. Katz, J. H. Iron and protein kinetics studied by means of doubly labeled human crystalline transferrin. J. clin. Invest. 1961, 40, 2143.

23. Rundles, R. W., and H. F. Falls. Hereditary (? sex linked) anemia. Amer. J. med. Sci. 1946, 211, 641.

24. Heilmeyer, L., J. Emmrich, H. H. Hennemann, H. Schubothe, W. Keiderling, M. H. Lee, R. Bilger, and $\mathrm{W}$. Bernauer. Uber eine neuartige hypochrome Anämie bei zwei Geschwistern auf der Grundlage einer Eisenverwertungsstorung: Anaemia sideroachrestica heriditaria. Schweiz. med. Wschr. 1957, 87, 1237.

25. Garby, L., S. Sjölin, and B. Vahlquist. Chronic refractory hypochromic anaemia with disturbed haemmetabolism. Brit. J. Haemat. 1957, 3, 55.

26. Caroli, J., J. Bernard, M. Bessis, A. Combrisson, R. Malassenet, and J. Breton-Gorius. Hémochromatose avec anémie hypochrome et absence d'hémoglobine anormale. Etude au microscope électronique. Présse méd. 1957, 65, 1991.

27. Heilmeyer, L. Les anémies sidéroachrestiques. Sang 1958, 29, 465.

28. Dacie, J. V., M. D. Smith, J. C. White, and D. L. Mollin. Refractory normoblastic anaemia: a clinical and haematological study of seven cases. Brit. J. Haemat. 1959, 5, 56.

29. Bernard, J., M. Bessis, M. Boiron, R. Malassenet, and $\mathrm{J}$. Caroli. Anémie hypochrome hypersidéremique sans anomalie de l'hémoglobine. Etude de 
métabolisme du fer effet de la pyridoxine. Rev. Hémat. 1960, 15, 318.

30. Bernard, J., M. Bessis, M. Boiron, P. Lortholary, R. Malassenet, and Y. Najean. Les ennemies hypochromes hypersidéremiques. Rev. Hémat. 1960, $15,341$.

31. Crosby, W. H., and T. W. Sheehy. Hypochromic iron-loading anaemia: studies of iron and haemoglobin metabolism by means of vigorous phlebotomy. Brit. J. Haemat. 1960, 6, 56.

32. Heilmeyer, L., W. Keller, O. Vivell, W. Keiderling, K. Betke, F. Wöhler, and H. E. Schultze. Congenital transferrin deficiency in a 7-year-old girl. Germ: med. Mth. 1961, 6, 385.

33. Heilmeyer, L., H. Merker, E. Mölbert, and M. Neidhardt. Zur Mikromorphologie der hereditären hypochromen sideroachrestischen Anämie. Acta haemat. 1962, 27, 78.

34. Verloop, M. C., M. Bierenga, and A. DiezeraadNjoo. Primary or essential sideroachrestic anaemias. Acta haemat. (Basel) 1962, 27, 129.

35. Gardner, F. H., and D. G. Nathan. Hypochromic anemia and hemochromatosis. Response to combined testosterone pyridoxine, and liver extract therapy. Amer. J. med. Sci. 1962, 243, 447.
36. Gelpi, A., and N. Ende. An hereditary anemia with hemochromatosis. Studies of an unusual hemopathic syndrome resembling thalassemia. Amer. J. Med. 1958, 25, 303.

37. Byrd, R. B., and T. Cooper. Hereditary iron-loading anemia with secondary hemochromatosis. Ann. intern. Med. 1960, 55, 103.

38. Bowdler, A. J., and E. R. Huehns. Thalassaemia minor complicated by excessive iron storage. Brit. J. Haemat. 1963, 9, 13.

39. Gale, E., J. Torrance, and T. Bothwell. The quantitative estimation of total iron stores in human bone marrow. J. clin. Invest. 1963, 42, 1076.

40. Bessis, M., and J. Breton-Gorius. Nouvelles observations sur l'ilot érythroblastique et la rhopheocytose de la ferritine. Rev. Hémat. 1959, 14, 165.

41. Bessis, M. C., and J. Breton-Gorius. Iron particles in normal erythroblasts and normal and pathological erythrocytes. J. biophys. biochem. Cytol. 1957, 3, 503.

42. Bothwell, T. H., and C. A. Finch. Iron Metabolism. Boston, Little, Brown, 1962, pp. 224-225.

43. Alpen, E. Discussion in Kinetics of Cellular Proliferation, F. S. Stohlman, Ed. New York, Grune \& Stratton, 1959, p. 29. 